\title{
Analytical Evaluation of Seismic Response Reduction Factor for Steel Frame Building by Using Various Types of Steel Bracing
}

\author{
Swapnil M. Patil , P. M. Pawar
}

\begin{abstract}
Now days steel structure has played an important role in all aspects of civil engineering. It is important to design a structure to perform well under seismic loads. The objective of the present study is to evaluate seismic response reduction factor( $R$ ) using various types of steel bracings. The $R$ factor of various types of frame is evaluated from nonlinear pushover analysis. The structure is analyzed in SAP2000 to check its adequacy compared to IS code recommended $R$ value. The $R$ factor components including ductility reduction factor and over strength factor obtained from inelastic pushover curve of braced frame systems for different heights and configurations for various types of frames are compared with IS code values. Method of analysis, design and evaluation data are presented in detail. Previous studies in literature and the theory of response reduction factor is also presented.
\end{abstract}

Index Terms-Bracings, Steel Frame Building, Nonlinear Static Pushover Analysis, Response Reduction factor.

\section{INTRODUCTION}

There are many natural hazards in the world but earthquakes are one of the most destructive natural hazards that can result in severe social and economic impact. In seismically active zones, structures are subjected to lateral earthquake forces in addition to bearing the primary gravity load. The performance of a structure during an earthquake depends on the intensity of the earthquake and the properties of the structure. In seismic events, the response of a steel structure is found to vary from elastic to highly inelastic. Steel structures should be designed to dissipate large amounts of energy during a severe seismic excitation, thus ensuring the sufficient lateral stiffness. Behavior of structures during recent earthquakes indicates that relying on just elastic analysis is not sufficient so that structures should behave as inelastic analysis. Earthquake loads are used to reduce to design loads by dividing by the Response reduction factors(R). Also by reducing earthquake loads structure will enter into inelastic range.

\section{A. Response Reduction Factor:}

Response Reduction Factor is a force reduction factor used to reduce the linear elastic response spectra to the inelastic response spectra. In other words, response reduction factor is the ratio of the strength required to maintain the structure elastic to the inelastic design strength of the structure. Response Reduction factor is first introduced in ATC-3-06 in 1978 , served to reduce the base shear force $\left(V_{e}\right)$ calculated by elastic analysis using a $2 \%$ damped acceleration response spectrum of steel structures for the purpose of calculating a design base shear $\left(\mathrm{V}_{\mathrm{b}}\right)$.

Swapnil Patil, Student, Department of Civil Engineering, Solapur University, SVERI's College of Engineering, Pandharpur

Prashant Pawar, Professor, Department of Civil Engineering, Solapur University, SVERI's College of Engineering Pandharpur



Fig.1: Bilinearization of Pushover Curve

Where, $\mathrm{V}_{\mathrm{e}}, \mathrm{V}_{\mathrm{u}}, \mathrm{V}_{\mathrm{y}}$ and $\mathrm{V}_{\mathrm{d}}$ correspond to the structure's elastic response strength, the idealized ultimate strength, the first significant yield strength and the design base shear, respectively. For structures designed using an ultimate strength method, the allowable stress factor, Y, becomes unity and the behavior factor is reduced to,

$$
\mathrm{R}=\mathrm{R} \mu * \mathrm{RS}
$$

The structure ductility, $\mu$ is defined in terms of maximum structural drift $(\Delta \max )$ and the displacement corresponding to the idealized yield strength $(\Delta y)$ as:

$$
\mu=\Delta \max / \Delta y
$$

Newmark and hall $(1973,1982)$ made the first attempt to relate ductility reduction factor $(\mathrm{R} \mu)$ with ductility $(\mu)$ they concluded that: i) For a structure of natural period less than $0.2 \mathrm{~s}$ i.e. short period structure the ductility does not help in reducing the response of the structure therefore, no ductility factor should be used.

Here, $\quad \mathrm{R}=1$

ii) For a moderate period structure ( $T=0.2$ to $0.5 \mathrm{~s}$ ) the energy that can be stored by elastic system at maximum displacement is the same as stored an inelastic system.

Here $\mathrm{R}=\sqrt{ }(2 \mu-1)$

iii) For relatively longer period structure the inertia force obtained from elastic and inelastic system cause the same displacement.

Here $\mathrm{R}=\mu$ 


\section{FLOWCHART OF MODELING THE STRUCTURES}

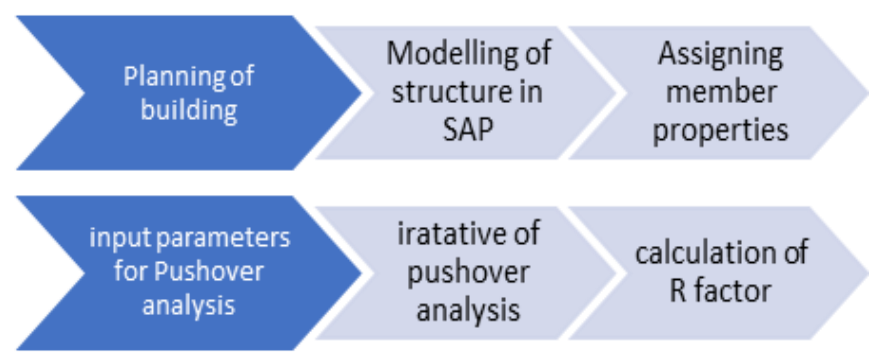

III. DETAILS OF MODEL

\section{A. Material Properties}

The material properties of the structural steel are as follows:

$\mathrm{E}=2 \times 105 \mathrm{~N} / \mathrm{mm} 2, \mu=0.3, F y=250 \mathrm{~N} / \mathrm{mm} 2$, Fck $=20$ $\mathrm{N} / \mathrm{mm} 2$, Bracings: ISA $200 \mathrm{X} 200 \mathrm{X} 18$, Beam I section : 250 X $125 \mathrm{~mm}$, Column I Section : 500 X $287 \mathrm{~mm}$.

\section{B. Model Geometry}

The model considered consists of 3 bays in $\mathrm{X}$ and $\mathrm{Y}$ directions. The dimensions in plan being $12 \mathrm{~m} * 12 \mathrm{~m}$. The floor to floor height is considered as $3.2 \mathrm{~m}$. The geometry of model used for the study has been tabulated as below:

\begin{tabular}{|c|c|}
\hline Bays along X direction & 3 \\
\hline Bays along Y direction & 3 \\
\hline Storey height & 3.2 \\
\hline $\begin{array}{c}\text { Bay width along X } \\
\text { direction }\end{array}$ & $4 \mathrm{~m}$ \\
\hline $\begin{array}{c}\text { Bay width along Y } \\
\text { direction }\end{array}$ & $4 \mathrm{~m}$ \\
\hline $\begin{array}{c}\text { Live load } \\
\text { Floor finish }\end{array}$ & $1.5 \mathrm{kN} / \mathrm{m}^{2}$ \\
\hline $\begin{array}{c}\text { Seismic zone } \\
\text { V }\end{array}$ \\
\hline $\begin{array}{c}\text { Importance factor } \\
\text { Response reduction } \\
\text { factor }\end{array}$ & 4 or 5 (depending on types of \\
& frame) \\
\hline Type of soil & Medium \\
\hline
\end{tabular}

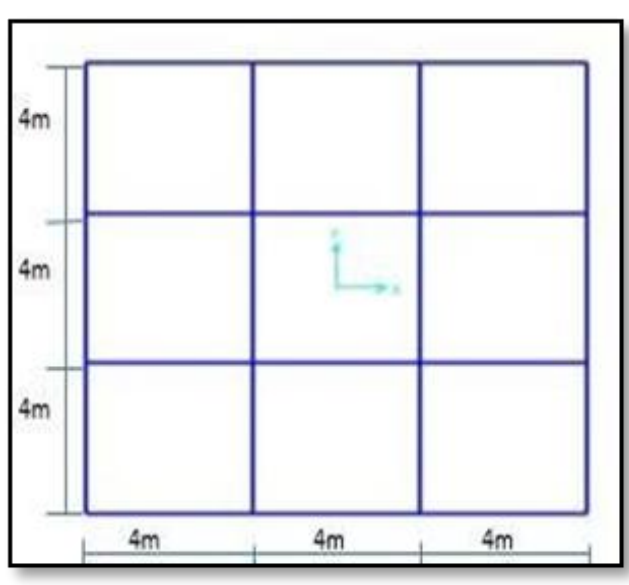

Fig.2: Plan of building

\section{ANALYSIS AND RESULT}

The components of Response Reduction factor have been computed and tabulated as shown. The relationship between various parameters has been depicted in figure :

Table.1. Components of R story wise

\begin{tabular}{|c|l|l|l|r|}
\hline Storey & Frame & $\mathbf{R}_{\boldsymbol{\mu}}$ & Rs & $\mathbf{R}$ \\
\hline \multirow{4}{*}{$\begin{array}{c}5 \\
\text { Storey }\end{array}$} & $\mathrm{MRF}$ & 2.05 & 4.17 & 8.54 \\
\cline { 2 - 5 } & $\mathrm{DBF}$ & 2.07 & 5.15 & 10.67 \\
\cline { 2 - 5 } & $\mathrm{XBF}$ & 2.30 & 5.37 & 12.34 \\
\cline { 2 - 5 } & $\mathrm{VBF}$ & 2.21 & 5.30 & 11.72 \\
\hline \multirow{4}{*}{$\begin{array}{c}\text { Storey } \\
\end{array}$} & $\mathrm{MRF}$ & 2.20 & 2.80 & 6.17 \\
\cline { 2 - 5 } & $\mathrm{DBF}$ & 1.80 & 3.52 & 6.32 \\
\cline { 2 - 5 } & $\mathrm{XBF}$ & 2.33 & 3.47 & 8.10 \\
\cline { 2 - 5 } & $\mathrm{VBF}$ & 2.24 & 3.50 & 7.81 \\
\hline \multirow{4}{*}{$\begin{array}{c}10 \\
\text { Storey }\end{array}$} & $\mathrm{MRF}$ & 1.96 & 2.35 & 4.59 \\
\cline { 2 - 5 } & $\mathrm{DBF}$ & 1.87 & 2.84 & 5.31 \\
\cline { 2 - 5 } & $\mathrm{XBF}$ & 1.89 & 2.84 & 5.35 \\
\cline { 2 - 5 } & $\mathrm{VBF}$ & 1.66 & 2.76 & 4.60 \\
\hline
\end{tabular}

Table .2. Components of R Frame wise

\begin{tabular}{|c|c|c|c|c|}
\hline Frame & storey & $\mathbf{R}_{\boldsymbol{\mu}}$ & $\mathbf{R s}$ & $\mathbf{R}$ \\
\hline \multirow{3}{*}{ MRF } & 5 & 2.05 & 4.17 & 8.54 \\
\cline { 2 - 5 } & 8 & 2.20 & 2.80 & 6.17 \\
\cline { 2 - 5 } & 10 & 1.95 & 2.35 & 4.59 \\
\hline \multirow{3}{*}{ DBF } & 5 & 2.07 & 5.15 & 10.67 \\
\cline { 2 - 5 } & 8 & 1.80 & 3.52 & 6.32 \\
\cline { 2 - 5 } & 10 & 1.87 & 2.84 & 5.31 \\
\hline \multirow{3}{*}{ XBF } & 5 & 2.30 & 5.37 & 12.34 \\
\cline { 2 - 5 } & 8 & 2.33 & 3.47 & 8.10 \\
\cline { 2 - 5 } & 10 & 1.89 & 3.47 & 6.56 \\
\hline \multirow{3}{*}{ VBF } & 5 & 2.21 & 5.30 & 11.72 \\
\cline { 2 - 5 } & 8 & 2.24 & 3.50 & 7.81 \\
\cline { 2 - 5 } & 10 & 1.66 & 2.76 & 4.60 \\
\hline
\end{tabular}


Table.3. Comparison of R Story wise with IS Code values

\begin{tabular}{|c|c|c|c|}
\hline Storey & Frame & $\begin{array}{c}\text { Value of R by } \\
\text { IS: 1893-2002 }\end{array}$ & $\begin{array}{c}\text { Actual R } \\
\text { Values }\end{array}$ \\
\hline \multirow{4}{*}{$\begin{array}{c}5 \\
\text { Storey }\end{array}$} & MRF & 5 & 8.54 \\
\cline { 2 - 4 } & DBF & 4 & 10.67 \\
\cline { 2 - 4 } & XBF & 4 & 12.3 \\
\hline \multirow{4}{*}{$\begin{array}{c}\text { Storey } \\
\end{array}$} & VBF & 4 & 11.72 \\
\cline { 2 - 4 } & DRF & 5 & 6.17 \\
\cline { 2 - 4 } & XBF & 4 & 6.32 \\
\cline { 2 - 4 } & VBF & 4 & 8.10 \\
\hline \multirow{3}{*}{\begin{tabular}{c} 
Storey \\
\cline { 2 - 4 }
\end{tabular}} & MRF & 5 & 7.81 \\
\cline { 2 - 4 } & DBF & 4 & 4.59 \\
\cline { 2 - 4 } & XBF & 4 & 5.31 \\
\cline { 2 - 4 } & VBF & 4 & 6.56 \\
\hline
\end{tabular}

\section{DISCUSSION}

The results from the study can be summarized as:

i) Response reduction factor increases with increase of over strength and ductility reduction factor.

ii) As storey height increases Response reduction factor decreases and vice-versa.

iii) Ductility reduction factor is maximum for MRF than all other braced frames.

iv) overstrength factor is higher than ductility reduction factor. From table over strength factor more by $51 \%, 21 \%$, $16 \%$ for 5, 8 and 10 storey for MRF than Ductility Reduction factor respectively.

v) From the above analysis it can be seen that the values recommended for $\mathrm{R}$ by IS 1893:2002 are on average or less by $41 \%, 62 \%, 67 \%$ and $65 \%$ for MRF, DBF, XBF and VBF respectively than actual value of $R$.

vi) From the analysis it can be seen that the value of $\mathrm{R}$ factor obtained from pushover curve are higher on XBF followed by VBF, DBF and MRF.

\section{REFERENCES}

[1] i) Mohammed Idrees Khan, Mr. Khalid Nayaz Khan, (2014) "Seismic Analysis Of Steel Frame With Bracings Using Pushover Analysis" International Journal of Advanced Technology in Engineering and Science, Vol 2, Pages 369-381.

[2] ii) K.K. Sangle, K.M. Bajoria, V. Mhalungkar, (2012) "Seismic Analysis of High Rise Steel Frame Building with and without Bracing" WCEE, 2012.

[3] iii) Mahmoud R. Maheri, R. Akbari, (2003) "Seismic behaviourfactor,R, for steel X -braced and knee-braced RC buildings" Engineering Structures Vol 25, Pages 1505-1513.

[4] iv) Dhanraj M. Patil, Keshav K. Sangle, (2015) "Seismic Behaviour of Different Bracing Systems in High Rise 2-D Buildings" Engineering Structures, Vol 3, Pages 282-305. 